\title{
ВИЗНАЧЕННЯ УМОВ ПРОНИКНЕННЯ ДЕФОРМАЦЇ̈ ПО ТОВЩИНІ ПРОКАТУ НА СТАНІ СТЕККЕЛЯ
}

Передові технології та новітнє устаткування, що набули розвитку останнім часом, дали поштовх для виробництва прокатної продукції з новим рівнем якісних характеристик, серед яких є вимоги до мікроструктури, частки в'язкої складової, підвищені вимоги до роботи удару та інші. При розробці нової технології та засвоєнні нового сортаменту, із забезпеченням підвищених вимог, виробники та вчені стикаються з проблемами, які потребують додаткового вивчення. Шляхом вирішення однієї з таких проблем, а саме забезпечення підвищених вимог до перелічених параметрів якості, $є$ дослідження впливу ступеня деформації на розподіл напруги, яка виникає в металі в процесі прокатки, та іiі проникнення по товщині прокату вздовж осередку деформації при різноманітних температурних умовах.

Серед методів досліджень, які проводяться для вивчення процесів прокатки, наразі, найбільш розповсюдженими є аналітичні методи [1-3] та методи математичного моделювання [4-10], які отримали своє поширення з розвитком комп'ютерних технологій.

Застосування методів математичного моделювання, серед яких найбільш поширеним $\epsilon$ метод скінчених елементів (MCE), у процесах обробки металів тиском дозволяє одночасно задовільнити декілька цілей: мінімізувати витрати на дослідження та розробку технологічних процесів в умовах реального виробництва, виконати поглиблене дослідження процесів пластичної деформації що відбуваються в дослідному осередку деформації, виконати порівняння результатів дослідження через математичне моделювання з фактичними результатами, отриманими при виробництві з метою виявлення вузьких місць технології. Серед інших, отримало поширення поглиблене вивчення шляхом використання методу скінчених елементів температурних процесів [11-13], які є невід'ємною складовою сучасної технології обробки металів тиском.

Через сучасний розвиток різноманітних варіантів технологічних процесів, таких як нормалізуюча прокатка, термомеханічна прокатка, з усіма іiї різновидами, засадами реалізації яких є взаємодія, при певних умовах, між температурою та деформацією, залишаються питання щодо їх комплексного дослідження та впливу на якість кінцевої продукції.

Метою цього дослідження $є$ отримання розподілу напруги по товщині прокату вздовж осередку деформації в умовах чорнової прокатки та в умовах квазістаціонарного розподілу температур при чистовій прокатці на стані Стеккеля. Порівняння результатів розрахунку, отриманих шляхом математичного моделювання з фактичними результатами прокатки.

Завдання роботи: а) дослідити розподіл напруги та деформації в умовах процесу прокатки на стані Стеккеля методом скінчених елементів; б) виконати порівняння результатів розрахунку силових параметрів прокатки, розрахованих шляхом математичного моделювання на базі програмного додатку Abaqus CAE 6.14-2 з фактичними результатами, отриманими на стані Стеккеля.

В роботі досліджено технологічний процес та силові характеристики стану Стеккеля заводу Ferriera Valsider, Італія. Схема основної технологічної лінії по виробництву гарячекатаних рулонів на заводі Ferriera Valsider наведена на рис. 1. Зовнішній вигляд ділянки стану Стеккеля наведений на рис. 2.

Характеристики дослідного сортаменту та фактичний режим прокатки наведено в табл. 1-3. 

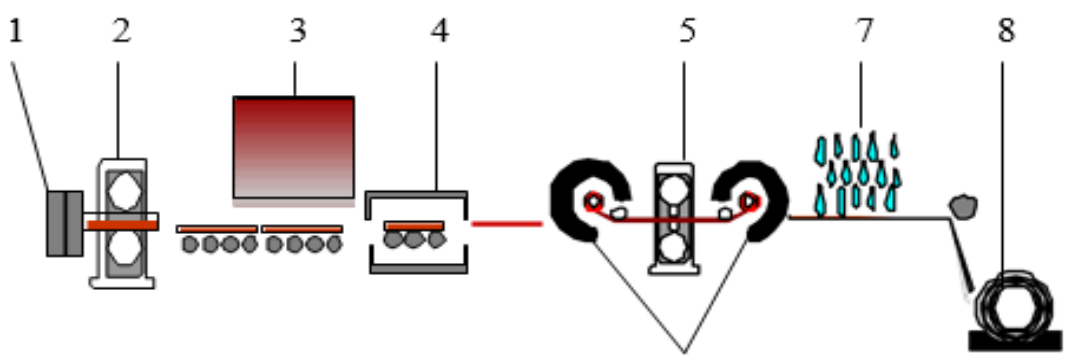

6

1 - кліть $з$ вертикальними валками;

2 - чорнова кліть 3170 ;

5 - кліть Стеккеля 1780;

3 - методична штовхальна піч;

6 - пічні моталки;

4 - прохідна роликова піч;

7 - установка ламінарного охолодження;

8 - моталка

Рис. 1. Схема технологічної лінії по виробництву гарячекатаних рулонів на заводі Ferriera Valsider

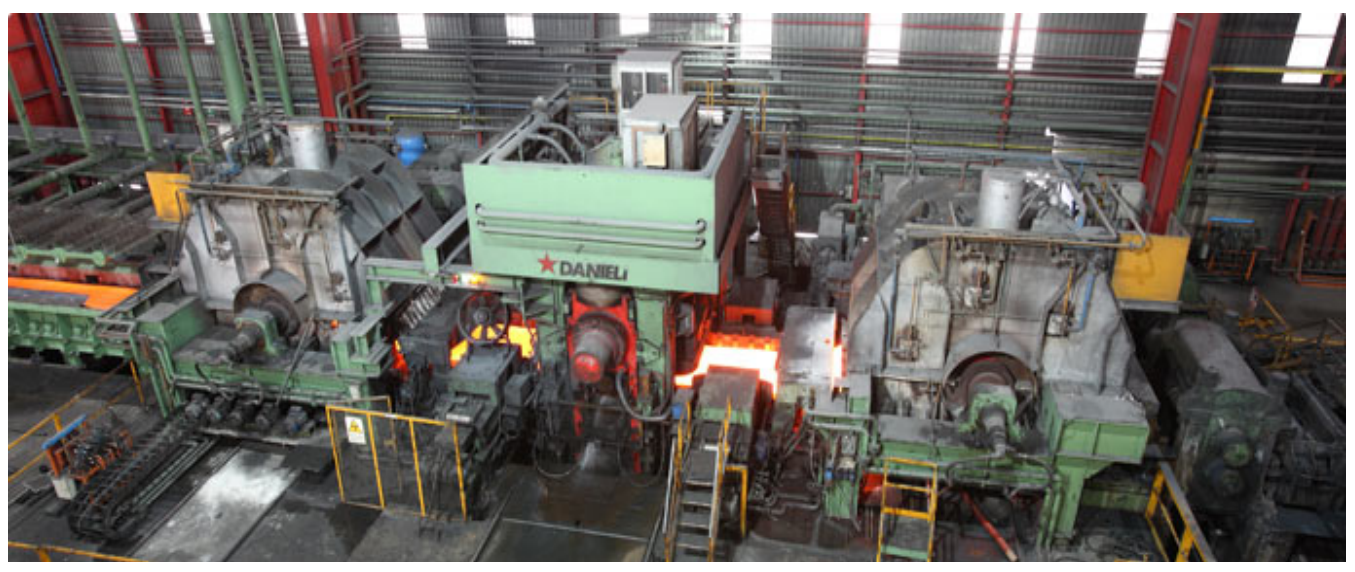

Рис. 2. Зовнішній вигляд ділянки стану Стеккеля

Таблиця 1

Сортамент слябів та рулонів, що досліджується

\begin{tabular}{|c|c|c|c|c|}
\hline $\begin{array}{c}\text { Шифр } \\
\text { плавки }\end{array}$ & № слябу & Марка сталі & Переріз слябу, мм & $\begin{array}{c}\text { Переріз рулону, } \\
\text { мм }\end{array}$ \\
\hline 81518 & $\mathrm{~A} 1 / 02005400$ & $\mathrm{~S} 355 \mathrm{JR}+\mathrm{AR}$ & $220 \times 1520 \times 9800$ & $15 \times 1500$ \\
\hline
\end{tabular}

Таблиця 2

Хімічній склад сталі марки S355JR + AR, що досліджувалася

\begin{tabular}{|c|c|c|c|c|c|c|c|c|c|c|c|c|c|c|c|}
\hline \multirow{2}{*}{$\begin{array}{c}\text { Шифр } \\
\text { плавки }\end{array}$} & $\mathrm{C}$ & $\mathrm{Si}$ & $\mathrm{Mn}$ & $\mathrm{P}$ & $\mathrm{S}$ & $\mathrm{Cr}$ & $\mathrm{Ni}$ & $\mathrm{Cu}$ & $\mathrm{Al}$ & $\mathrm{Ti}$ & $\mathrm{Nb}$ & $\mathrm{Mo}$ & $\mathrm{V}$ & $\mathrm{N}$ & As \\
\hline 81518 & 0.14 & 0.023 & 1.40 & 0.014 & 0.003 & 0.05 & 0.18 & 0.02 & 0.035 & 0.005 & 0.034 & 0.01 & 0.005 & 0.007 & 0.005 \\
\hline
\end{tabular}

Слід зазначити, що з метою виключення помилок розрахунку, пов'язаних з фіксацією фактичної температури прокатки по проходах на стані, в математичній моделі в системі Abaqus CAE було використано результати розрахунку здійсненого аналітичним способом [14]. Для побудови моделі фізико-механічних властивостей металу, що обробляється в системі CAE (Complete Abaqus Environment), необхідно задати його щільність, пружність та пластичні властивості. 
Скінчено-елементна модель процесу гарячої прокатки побудована для процесу прокатки сталі марки S355JR + AR згідно з вимогами EN 10025-2, з хімічним складом, що наведений в табл. 2.

Таблиця 3

Фактичний режим прокатки плавки № 81518 по клітях стану Стеккеля

\begin{tabular}{|c|c|c|c|c|c|c|c|c|}
\hline 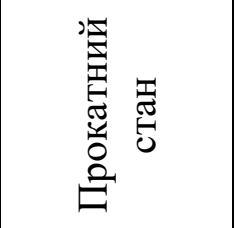 & 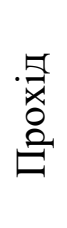 & 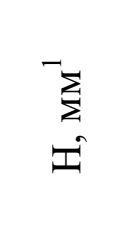 & $\begin{array}{l}\sum_{\Sigma} \\
\varepsilon \\
=\end{array}$ & 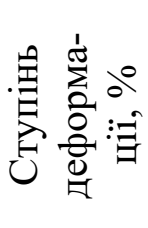 & 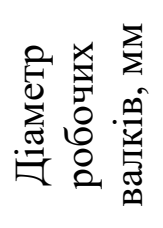 & 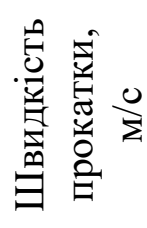 & 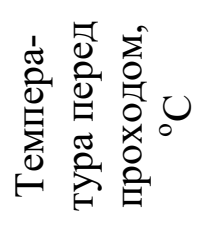 & 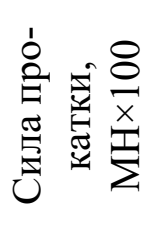 \\
\hline \multirow{11}{*}{$\begin{array}{c}\text { Стан дуо } \\
1780\end{array}$} & 1 & 221.3 & 200.49 & 9.40 & 1050 & 2.20 & 1090 & 1007 \\
\hline & 2 & 200.49 & 178.82 & 10.81 & 1050 & 2.20 & 1068 & 904 \\
\hline & 3 & 178.82 & 158.36 & 11.44 & 1050 & 2.20 & 1068 & 1000 \\
\hline & 4 & 158.36 & 139.55 & 11.88 & 1050 & 2.20 & 1044 & 1017 \\
\hline & 5 & 139.55 & 120.54 & 13.62 & 1050 & 2.20 & 1073 & 1015 \\
\hline & 6 & 120.54 & 103.88 & 13.82 & 1050 & 2.20 & 1023 & 1077 \\
\hline & 7 & 103.88 & 87.23 & 16.03 & 1050 & 2.20 & 1055 & 1121 \\
\hline & 8 & 87.23 & 71.81 & 17.68 & 1050 & 2.20 & 1009 & 1243 \\
\hline & 9 & 71.81 & 57.87 & 19.41 & 1050 & 2.20 & 1027 & 1254 \\
\hline & 10 & 57.87 & 46.82 & 19.09 & 1050 & 2.20 & 1027 & 1246 \\
\hline & 11 & 46.82 & 37.16 & 20.63 & 1050 & 2.20 & 1041 & 1397 \\
\hline \multirow{3}{*}{$\begin{array}{c}\text { Стан кварто } \\
1780 \\
\text { (Стеккеля) }\end{array}$} & 1 & 37.16 & 23.95 & 35.55 & 620 & 4.06 & 999 & 1957 \\
\hline & 2 & 23.95 & 18.98 & 20.75 & 620 & 4.06 & 958 & 1351 \\
\hline & 3 & 18.98 & 15.17 & 20.07 & 620 & 4.06 & 920 & 1195 \\
\hline
\end{tabular}

1,2 товщина перед та після проходу, мм

В системі Abaqus CAE були задані наступні параметри: щільність 7.8E-09 т/мм³ ; коефіцієнт Пуассона - 0.3. Модуль пружності був заданий в залежності від температури металу $t,{ }^{\circ} \mathrm{C}$ по наступній залежності [15]:

$$
E=\left(213,286-4,877 \cdot 10^{-2} t-3,33 \cdot 10^{-5} t^{2}-2,778 \cdot 10^{-8} t^{3}\right) \cdot 10^{3}, \text { МПа }
$$

Істинний опір деформації $\sigma_{s}$ було визначено згідно 3 методом Л. В. Андреюка та Г. Г. Тюленева, по хімічному складу [16]:

$$
\sigma_{s}=S_{\sigma O D} \cdot u^{a} \cdot(10 \varepsilon)^{b}(t / 1000)^{c},
$$

де $u$ - швидкість деформації, $\mathrm{c}^{-1}$;

$\varepsilon$ - відносна ступінь деформації, відн. од;

$t$ - температура деформації, ${ }^{\circ} \mathrm{C}$;

$S_{\sigma O D}, a, b, c$ - коефіцієнти для кожної марки сталі, які визначаються по відповідних залежностях з урахуванням хімічного складу [16].

Перетворення отриманих методом Л. В. Андреюка та Г.Г. Тюленева значень опору деформації (напруги) $\sigma_{S_{\text {true }}}$ та ступеня деформації $\varepsilon_{i n}^{p l}$ для застосування в середовищі Abaqus САЕ виконували по наступній методиці:

$$
\begin{gathered}
\sigma_{S_{\text {true }}}=\sigma_{s}(1+\varepsilon) ; \\
\varepsilon_{\text {true }}=\ln (1+\varepsilon) ; \\
\varepsilon_{\text {in }}^{p l}=\varepsilon_{\text {true }}-\left(\sigma_{S_{\text {true }}} / E\right) .
\end{gathered}
$$


Істинний опір деформації в середовищі Abaqus CAE, $\sigma_{S_{\text {true }}}$, було задано в залежності від: ступеня деформації $\varepsilon$ в діапазоні от $0.0 \ldots 0.8$ відн. од; швидкості деформації $u$ в діапазоні от $0.0 \ldots 40.0 \mathrm{c}^{-1}$; температури деформації $t$ в діапазоні $800 \ldots 1200{ }^{\circ} \mathrm{C}$.

В розрахунках по формулі (2), для отримання в системі Abaqus CAE нульових значень для ступеня деформації та швидкості деформації використовувались відповідно до значень, які дорівнювали 0.001 та 0.01. Значення опору деформації (напруги) $\sigma_{S_{\text {true }}}$ та ступеня деформації $\varepsilon_{i n}^{p l}$ було розраховано по формулах (3) та (5). Для зменшення часу розрахунків в моделі, згідно з рекомендаціями розробника програмного забезпечення, було використано симетрію процесу.

Обробка результатів скінчено-елементного моделювання полягала в аналізі полів напруги та деформації. Для аналізу енергосилових параметрів процесу прокатки використовували реакції у довідковій точці валка. Графіки, що були отримані в середовищі Abaqus CAE, експортували в MS Excel у числовому вигляді та піддавали статистичній обробці.

Результати розрахунку процесу прокатки на стані Стеккеля в середовищі Abaqus CAE. Розрахунок процесів прокатки сталі марки S355JR+AR зі слябу розмірами $220 \times 1520 \times 9800$ мм та кінцевими розмірами рулону $15 \times 1500$ мм в середовищі Abaqus CAE здійснювали по проходах для чорнової кліті, стан 3170 та для стану 1780 з пічними моталками (Стеккеля) з урахуванням особливостей технології та устаткування. Результати розрахунків полів еквівалентної напруги $\mathrm{S}$, еквівалентної пластичної деформації PEEQ по показових проходах в кліті стану 3170 наведено на рис. 3. Слід зазначити, що на рисунках, поля еквівалентної напруги S мають розмірність «МПа», поля еквівалентної пластичної деформації PEEQ мають розмірність «відн. од.».

Виходячи з динаміки змінення полів інтенсивності або рівня еквівалентної напруги $S$ по шарах, можна зробити висновок щодо проникнення деформації по товщині прокату. Як відомо, кінцеві властивості прокату починають формуватися на стадії чорнової прокатки. Тому, отримання даних щодо настання такої фази в металі дозволяє покращити процеси проектування, розробки та вдосконалення технології в прив'язці до характеристик конкретного стану та матеріалу що обробляється.

При моделюванні режимів прокатки сталі марки S355JR+AR в кліті стану 3170, початок проникнення деформації на всю глибину заготовки, по товщині, спостерігається в шостому проході, в якому починає формуватися суцільний шар або поле напруги, яке дорівнює 90 \% від максимальної еквівалентної напруги в цьому проході, при інших відповідних умовах прокатки. При цьому еквівалентна ступінь деформації на виході з осередку деформації по шарах, в залежності від глибини проникнення в товщину прокату, варіюється від 0,121 відн. од. до 0,208 відн. од, різниця складає 0,087 відн. од.

При подальшій прокатці, в наступних проходах, відбувається збільшення довжини цього суцільного поля напруги, разом зі збільшенням величини еквівалентної пластичної деформації. В проході 8 вже спостерігається формування шару з максимальної напруги з подальшим його розширенням та змішування 3 шаром напруги, який дорівнює $90 \%$, з урахуванням розмірів осередку деформації. При цьому еквівалентна ступінь деформації на виході з осередку деформації по шарах, в залежності від глибини проникнення в товщину прокату, варіюється від 0.184 відн. од. до 0.246 відн. од., різниця складає 0.062 відн. од.

На підставі отриманих результатів можна зробити висновок, що технологічна ефективність процесу прокатки, який моделюється, починає відбуватися 3 шостого проходу. Деформація, яка здійснюється до шостого проходу, спрямована здебільшого лише на досягнення необхідної форми прокату/заготовки. Під технологічною ефективністю мається на увазі здійснення процесу прокатки з суттєвим впливом на внутрішні процеси, що відбуваються по всій товщині, а не тільки на поверхневих шарах прокату.

При моделюванні режимів прокатки сталі марки S355JR+AR в кліті стану 1780 (Стеккеля), по всіх трьох проходах спостерігається проникнення деформації на всю глибину заготовки, по товщині, при інших відповідних умовах прокатки. При цьому еквівалентна ступінь 
деформації на виході з осередку деформації по шарах є майже однаковою по всій глибини/товщині прокату та має наступні відповідні значення: 0.422 відн. од., 0.228 відн. од., та 0.208-0.238 відн. од.

Результати розрахунку полів еквівалентної напруги $S$ та еквівалентної пластичної деформації PEEQ по проходах в кліті стану 1780 (Стеккеля) наведено на рис. 4.
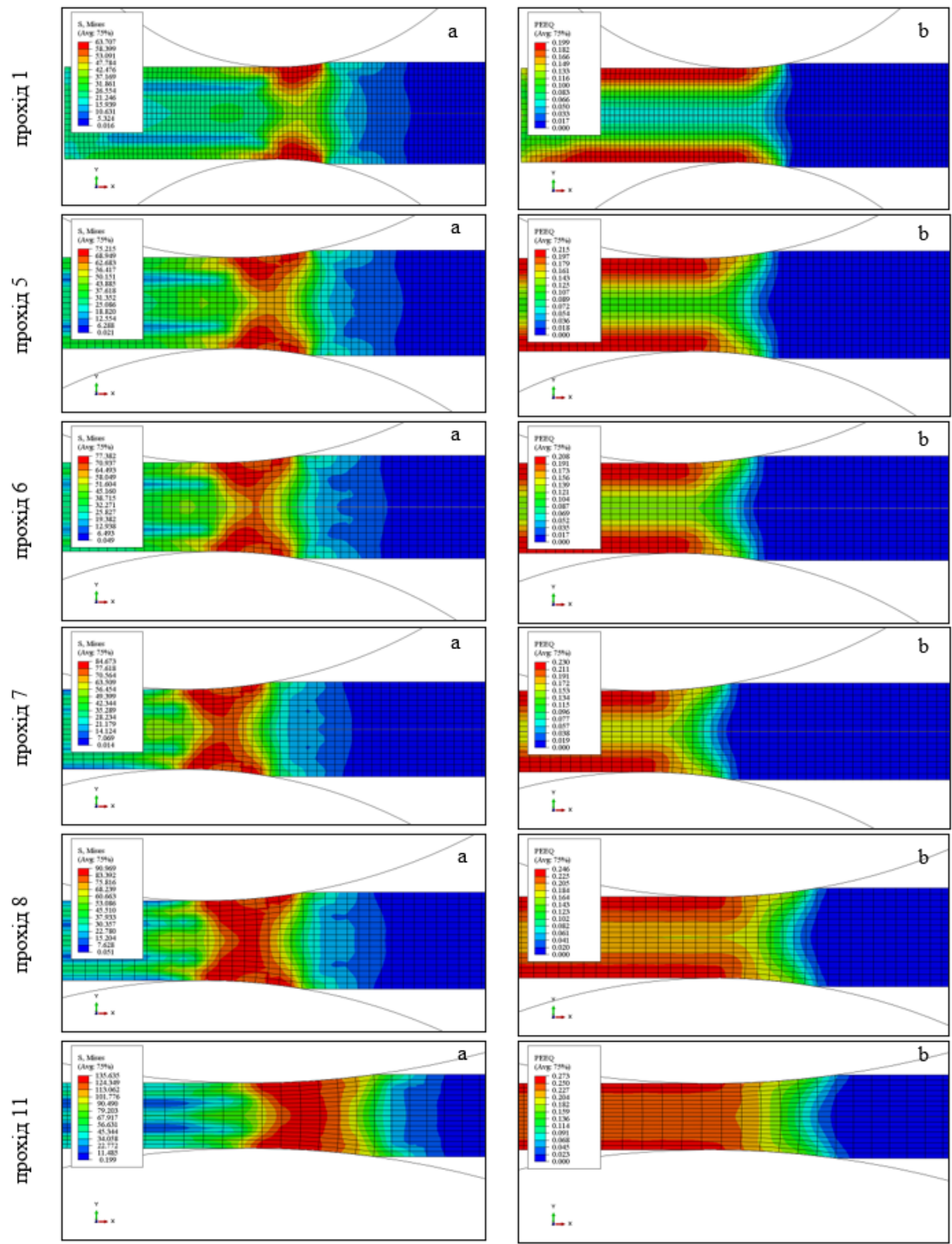

Рис. 3. Результати розрахунків полів еквівалентної напруги (а) та еквівалентної пластичної деформації (б) по проходах на стані 3170 

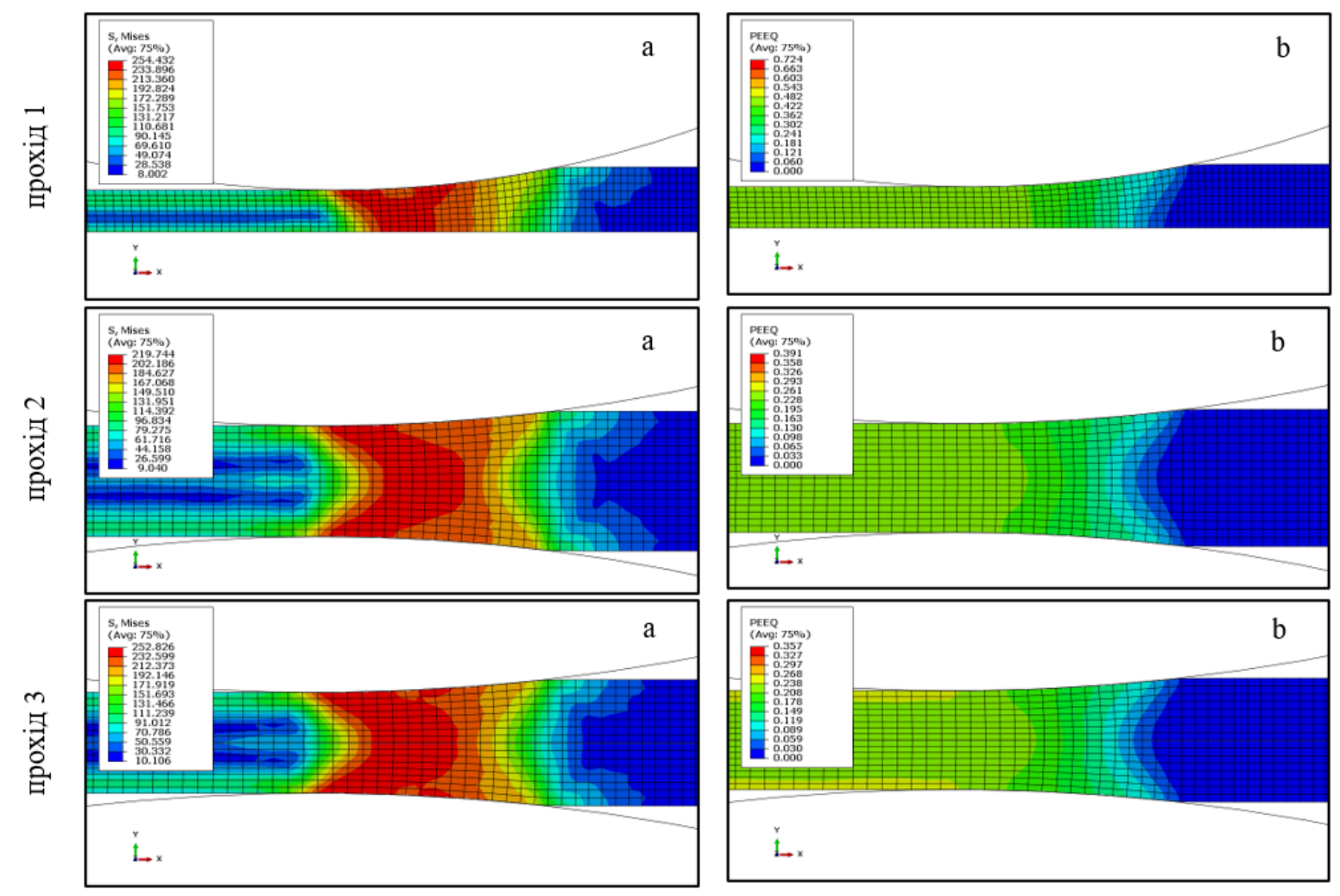

Рис. 4. Результати розрахунків полів еквівалентної напруги (а) та еквівалентної пластичної деформації (б) по проходах на стані 1780 (Стеккеля)

На підставі отриманих результатів можна зробити висновки, що при прокатці в кліті стану 1780 (Стеккеля), по всіх проходах, проникнення деформації здійснюється на всю товщину прокату. Максимальна еквівалентна напруга та напруга, яка дорівнює 90 \% від максимальної, мають суцільний шар по всій товщині прокату з урахуванням розмірів осередку деформації.

Аналіз даних по результатах скінчено-елементного моделювання прочесу прокатки рулонів на стані Стеккеля. Результати розрахунків по проходах, отриманих за допомогою скінчено-елементного моделювання, порівнювали з фактичними результатами прокатки рулонів розмірами $15 \times 1500$ мм зі сталі марки S355JR+AR. Додатково, з метою виявлення відхилень, пов'язаних з фіксацією фактичних показників прокатки, виконано аналогічні розрахунки за допомогою вдосконаленої аналітичної моделі технологічного процесу прокатки [14]. Порівняння результатів розрахунків температури та сили прокатки наведено в табл. 4.

На підставі порівняльних розрахунків встановлено, що отримані відхилення сили прокатки між двома способами розрахунку та фактичними даними мають зіставні результати та схожу тенденцію змінення по проходах, рис. 5. Середнє значення отриманих відхилень не перевищує $1.54 \%$ та $-1.77 \%$ та свідчить про високу точність отриманих результатів розрахунків по обох способах розрахунку.

Виконаний аналітичним способом перевірочний розрахунок змінення температури смуги по проходах, який було використано при математичному моделюванні, підтвердив наявність значних відхилень в фактичних температурах чорнової прокатки, що може бути пов'язане $з$ місцем встановлення технологічних пірометрів та наявністю пари. Таким чином, підтверджено правомірність використання розрахованих аналітичним способом температур прокатки для скінчено-елементного моделювання. Відомо, що середній тиск є усередненою величиною між напругою, яка з'являється в окремих шарах по товщині заготовки в процесі прокатки, та напругою від впливу процесів позаконтактної деформації. 


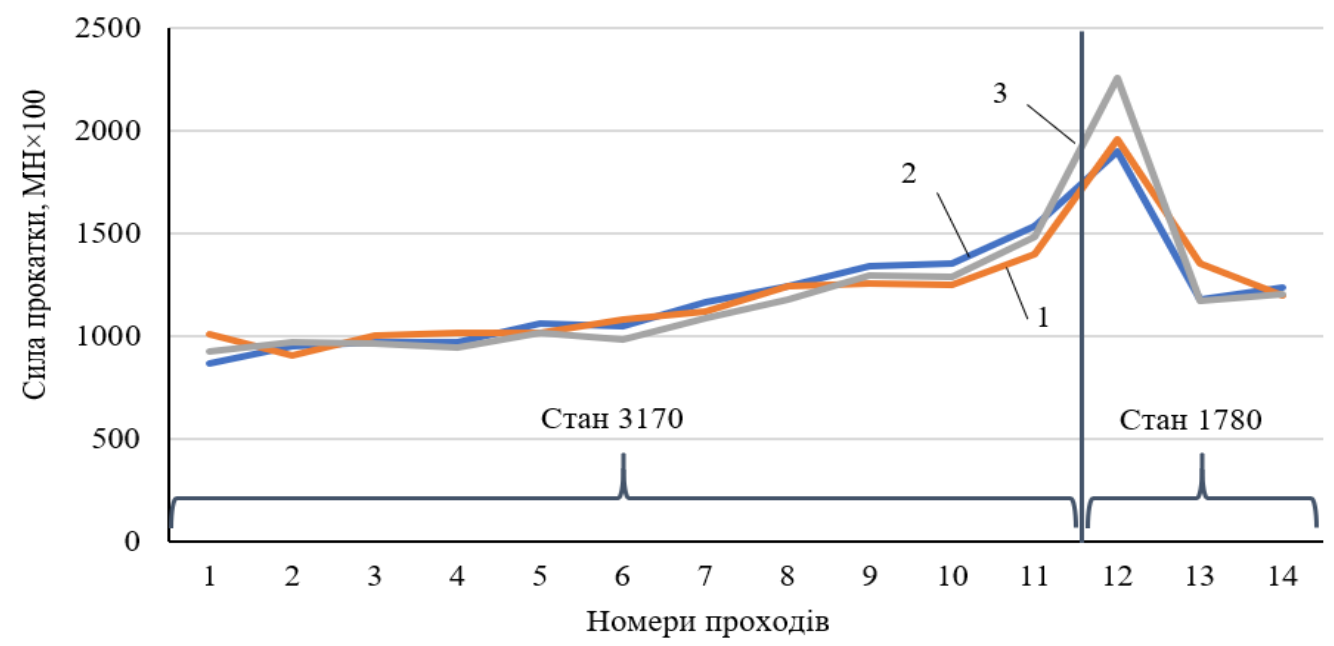

Рис. 5. Зміна сили прокатки по проходах по фактичних даних (1), по аналітичних розрахунках (2), по результатах математичного моделювання (3)

Таблиця 4

Порівняння фактичних результатів прокатки рулонів розмірами $15 \times 1500$ мм зі сталі марки $\mathrm{S} 355 \mathrm{JR}+\mathrm{AR}$ на стані Стеккеля з результатами розрахунків

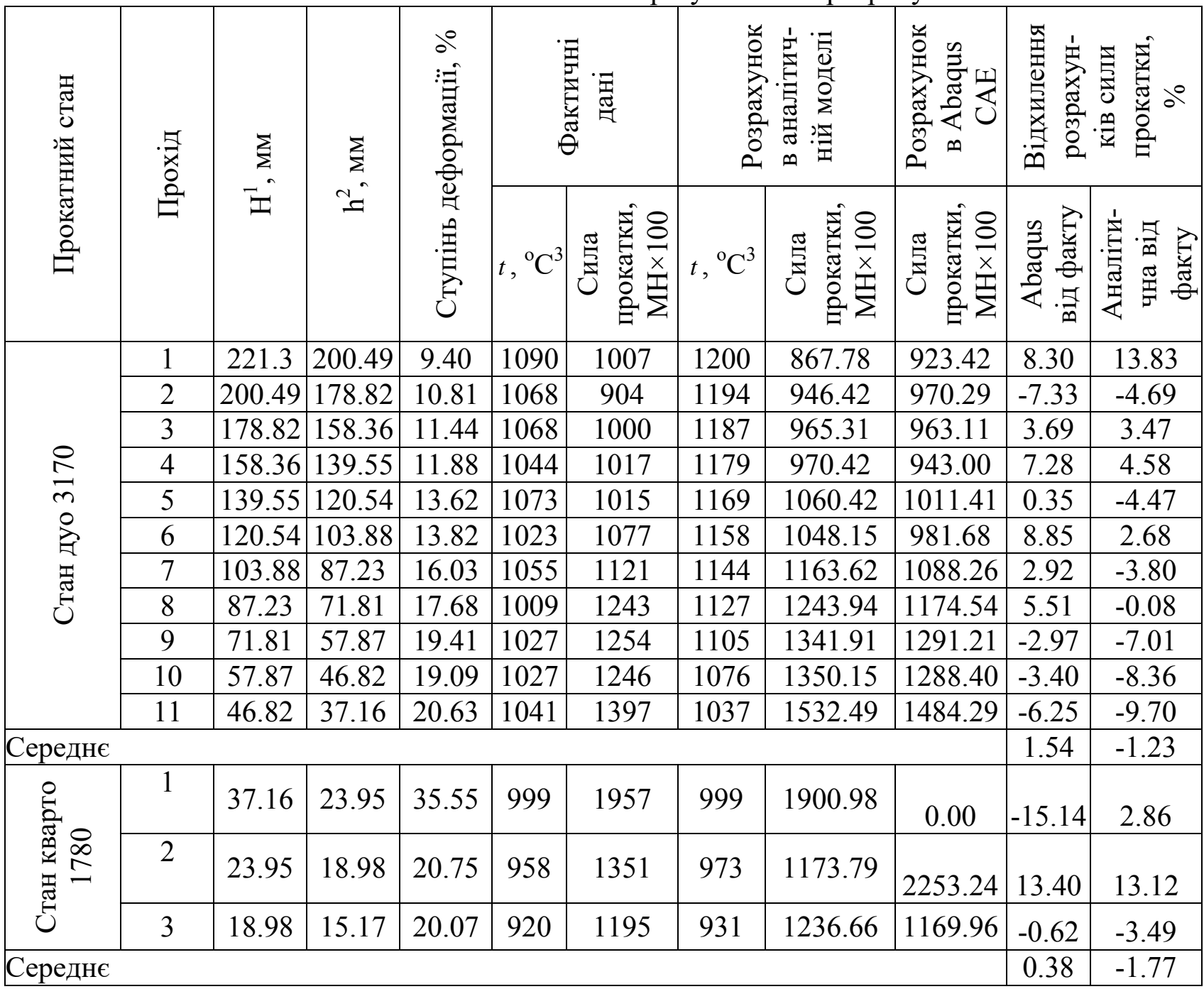

1,2 товщина перед та після проходу, мм

3 температура перед проходом 
По результатах математичного моделювання визначено рівні еквівалентної напруги по кожному шару у осередку деформації, обробка яких в Excel дозволяє визначити величину, яка $є$ порівняною з середнім тиском. На підставі цього, та результатів аналітичних розрахунків на чорновій стадії прокатки можна визначити початок формування суцільного шару еквівалентної напруги при чорновій прокатці, тобто початок проникнення деформації по всій товщині заготовки. Результати розрахунків наведено в табл. 5.

Таблиця 5

Результати розрахунку для визначення початку формування суцільного шару еквівалентної напруги при чорновій прокатці на стані 3170

\begin{tabular}{|l|c|c|c|c|c|c|c|c|c|c|c|}
\hline \multicolumn{1}{|c|}{ Параметр } & \multicolumn{7}{|c|}{ Значення параметру по номерах проходів } \\
\hline Прохід & 1 & 2 & 3 & 4 & 5 & 6 & 7 & 8 & 9 & 10 & 11 \\
\hline Середній тиск, МПа & 54.80 & 58.57 & 61.48 & 64.46 & 70.06 & 73.98 & 82.15 & 91.26 & 103.54 & 117.01 & 142.04 \\
\hline $\begin{array}{l}\text { Максимальний рівень } \\
\text { еквівалентної напруги, S, } \\
\text { МПа }\end{array}$ & 63.71 & 66.42 & 67.50 & 70.94 & 75.22 & 77.38 & 84.67 & 90.97 & 104.30 & 116.85 & 135.64 \\
\hline $\begin{array}{l}\text { Відхилення між S та } \\
\text { середнім тиском, \% }\end{array}$ & 13.98 & 11.82 & 8.92 & 9.14 & 6.85 & 4.40 & 2.98 & -0.32 & 0.73 & -0.13 & -4.72 \\
\hline Ступінь деформації, \% & 9.40 & 10.81 & 11.44 & 11.88 & 13.62 & 13.82 & 16.03 & 17.68 & 19.41 & 19.09 & 20.63 \\
\hline
\end{tabular}

розраховано за допомогою аналітичної моделі

Перетин між кривою зміни відхилення між максимальним рівнем еквівалентної напруги та середнім тиском і кривою зміни ступеня деформації по проходах $є$ початком та відповідною умовою проникнення деформації по всій товщині заготовки при чорновій прокатці на стані 3170, рис. 6. Таким чином, визначено, що початок формування суцільного шару еквівалентної напруги при чорновій прокатці, а відповідно і початок проникнення деформації по всій товщині заготовки, відбувається у проході 6 за умов деформації, що дорівнює 0,14 відн. од. (14\%). Змінення відхилення по проходах з позитивних до негативних значень можливо пояснити як процес балансування між збільшенням шару еквівалентної напруги у осередку деформації та зменшенням, в порівнянні із цим, впливу позаконтактної деформації. При чистовій прокатці на стані Стеккеля деформація, яка відбувається, є достатньою та проникає по всій товщині прокату. Відповідно, до цього криві зміни відхилення між максимальним рівнем еквівалентної напруги та середнім тиском та кривою зміни ступеня деформації не перетинаються, рис. 7.

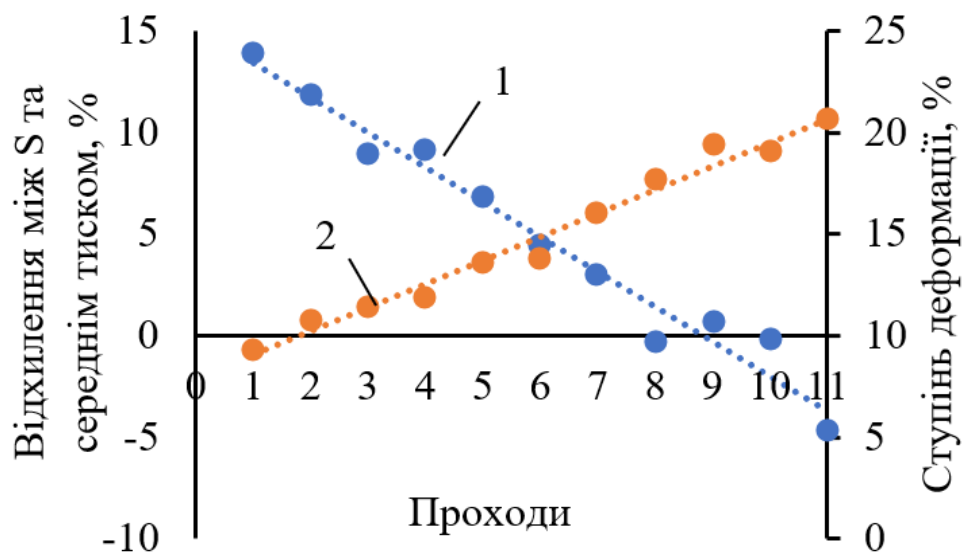

Рис. 6. Визначення початку та умов проникнення деформації по товщині заготовки при чорновій прокатці на стані 3170 по кривих зміни відхилення між максимальним рівнем еквівалентної напруги та середнім тиском (1) та кривою зміни ступеня деформації (2) 


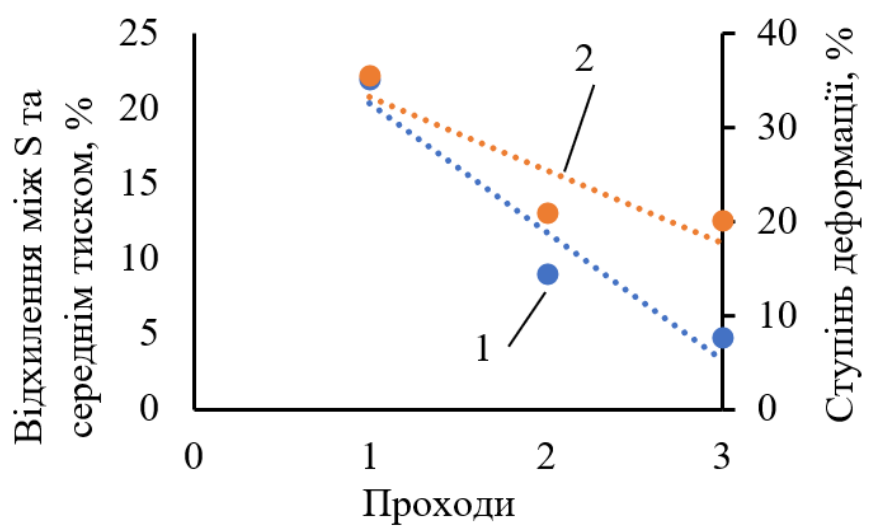

Рис. 7. Визначення стану проникнення деформації по товщині заготовки при чистовій прокатці на стані 1780 по кривих зміни відхилення між максимальним рівнем еквівалентної напруги та середнім тиском (1) та кривою зміни ступеня деформації (2)

На підставі отриманих результатів математичного моделюванням процесу прокатки на стані Стеккеля методом скінчених елементів встановлено межу початку проникнення деформації по всій товщині заготовки при чорновій прокатці конструкційної марки сталі S355JR + AR, яка дорівнює $14 \%$.

При чистовій прокатці по всіх проходах, в умовах квазістаціонарного розподілу температур на стані Стеккеля деформація, яка відбувається, є достатньою та проникає по всій товщині прокату. Такий стан та відповідна динаміка пов'язані здебільшого з товщиною заготовки при чистовій прокатці.

Отримані результати дозволяють керувати процесами внутрішньої якості та комплексом властивостей прокату, які необхідно отримати шляхом розробки відповідних технологічних режимів із врахуванням проникнення деформації по товщині прокату.

\section{ВИСНОВКИ}

Виконано дослідження процесів гарячої прокатки в умовах стану Стеккеля шляхом математичного моделювання методом скінчених елементів в системі Abaqus CAE на прикладі виробництва рулонів розмірами $15 \times 1500$ мм з конструкційної сталі марки S355JR + AR згідно з вимогами EN 10025-2.

По результатах моделювання отримано розподіл полів напруги та деформації по проходах, також розраховано енергосилові параметри процесу прокатки. Виконано порівняння енергосилових параметрів отриманих методом скінчених елементів та розрахованих аналітичним методом 3 фактичними даними по результатах прокатки рулонів розмірами $15 \times 1500$ мм 3 конструкційної сталі марки S355JR + AR на стані Стеккеля. Середнє значення відхилень не перевищує $1,54 \%$ та $-1,77$ \% відповідно, що свідчить про високу точність отриманих результатів обома способами розрахунку.

Вперше, на підставі отриманих результатів математичного моделюванням процесу прокатки на стані Стеккеля методом скінчених елементів встановлено межу початку проникнення деформації по всій товщині заготовки при чорновій прокатці конструкційної марки сталі S355JR + AR, яка дорівнює ступеню деформації 14 \%, що відповідає проходу № 6.

Встановлено, що при чистовій прокатці, по всіх проходах, в умовах квазістаціонарного розподілу температур на стані Стеккеля деформація, яка відбувається, є достатньою та проникає по всій товщині прокату.

Результати отримані методом скінчено-елементного моделювання дозволяють керувати процесами внутрішньої якості та комплексом властивостей прокату, які необхідно отримати шляхом розробки відповідних технологічних режимів із врахуванням проникнення деформації по товщині прокату. Отримані результати можуть бути використані для розробки технології гарячої прокатки (з однією або декількома стадіями чорнової прокатки) на інших типах станів та комплексів основного устаткування зі схожими технологічними параметрами. 


\section{REFERENCES}

1. Kim J., Lee J., Hwang S.M. An analytical model for the prediction of strip temperatures in hot strip rolling. International journal of heat mass transfer. 2009. 52, pp. 1864-1874.

2. Kurpe O.H., Kukhar V.V., Klimov E.S., Chernenko S.M. Improvement of Process Parameters Calculation for Coil Rolling at the Steckel Mill. Materials Science and Metallurgical Technology II. Materials Science Forum. 2020. 989, pp. 609-614. DOI: https://doi.org/10.4028/www.scientific.net/MSF.989.609

3. Kurpe O.H., Kukhar V.V. Development and Optimization of Flat Products Manufacturing at Rolling Mill 3200. Materials Science and Metallurgical Technology. Materials Science Forum. 2018. 946, pp. 794-799. DOI: https://doi.org/10.4028/www.scientific.net/MSF.946.794

4. $\mathrm{Xu}$ Yunbo, Yu Yongmei, Liu Xianghua, Wang Guodong. Modeling of microstructure evolution and mechanical properties during hot-strip rolling of $\mathrm{Nb}$ steels. Journal of University of Science and Technology. Beijing. 2008, 15, pp. 396-401. DOI: https://doi.org/10.1016/S1005-8850(08)60075-4

5. Schausberger F., Steinboeck A., Kugi A. Mathematical modeling of the contour evolution of heavy plates in hot rolling. Applied Mathematical Modelling. 2015. 39, pp.4534-4547. DOI: https://doi.org/10.1016/j.apm.2015.01.017

6. Quan-Ke Pan, Qing-da Chen, Tao Meng, Bing Wang, Liang Gao. A mathematical model and two-stage heuristic for hot rolling scheduling in compact strip production. Applied Mathematical Modelling. 2017. 48, pp. 516533. DOI: https://doi.org/10.1016/j.apm.2017.03.067

7. Rudkins N., Evans P. Mathematical modelling of mill set-up in hot strip rolling of high strength steels. Journal of Materials Processing Technology. 1998. 80-81, pp. 320-324. DOI: https://doi.org/10.1016/S0924$\underline{0136(98) 00190-3}$

8. Ettl A., Prinz K., Mueller M., Steinboeck A., Kugi A. Mathematical Model and Stability Analysis of the Lateral Plate Motion in a Reversing Rolling Mill Stand. IFAC-PapersOnLine. 2018. 51. 2, pp. 73-78.

DOI: https://doi.org/10.1016/j.ifacol.2018.03.013

9. Phaniraj M.P., Behera B.B., Lahiri A.K. Thermo-mechanical modeling of two phase rolling and microstructure evolution in the hot strip mill Part I. Prediction of rolling loads and finish rolling temperature. Journal of Materials Processing Technology. 2005. 170, pp. 323-335.

10. Kukhar V.V., Nikolenko R.S. Investigation of the stress-strain state of blanks during profiling with convex plates with eccentricity of the load. Problems of Tribology. 2012. 3, pp. 132-136. (in Russian).

11. Weisz-Patrault Daniel. Coupled heat conduction and multiphase change problem accounting for thermal contact resistance. International Journal of Heat and Mass Transfer. 2017, pp. 595-606. DOI: https://doi.org/10.1016/j.ijheatmasstransfer.2016.08.091

12. Weisz-Patrault Daniel, Ehrlacher Alain, Legrand Nicolas. Temperature and heat flux fast estimation during rolling process. International Journal of Thermal Sciences. 2014, pp. 1-20. DOI: https://doi.org/10.1016/j.ijthermalsci.2013.07.010

13. Weisz-Patrault Daniel. Inverse three-dimensional method for fast evaluation of temperature and heat flux fields during rolling process. Symposium on Modelling of Rolling Processes. France. 2012, pp. $20-22$.

14. Kurpe O.H., Kukhar V.V., Zmaznyeva Ye.V. Clarification of the calculation of metal heat losses at the Steckel mills. Problems of Tribology. 2018. 1, pp. 78-84. (in Ukrainian).

15. Fedorinov V.A., Satonin A.V., Gribkov Je.P. The mathematical modeling of stresses, deformations and basic quality indicators during rolling of relatively wide sheets and strips. monogr. Kramatorsk. DGMA. 2010.244 p. (in Russian).

16. Konovalov Ju.V., Ostapenko A.L., Ponomarev V.I. Calculation of sheet rolling parameters. Directory. Moscow. Metallurgy. 1986. 430 p. (in Russian).

Курпе О. Г. - канд. техн. наук, ст. наук. співробітник ПДТУ; E-mail: aleksandr.kurpe@gmail.com; https://orcid.org/0000-0003-2039-7239

Кухар В. В. - д-р техн. наук, проф., ПДТУ.

E-mail: kvv.mariupol@gmail.com; https://orcid.org/0000-0002-4863-7233

ПДТУ - ДВНЗ «Приазовський державний технічний університет», м. Маріуполь. 